\title{
Prevalence of antibody to Hepatitis B core antigen and Hepatitis $B$ virus DNA in HBsAg negative healthy blood donors
}

\author{
Gharib Karimi, Maryam Zadsar ${ }^{*}$, Nasrin Vafaei, Zohreh Sharifi and Mohammad FalahTafti
}

\begin{abstract}
Background: Hepatitis B virus is one of the most important blood born viruses. Although the sensitivity of screening tests has been considerably increased, transmission may still occur due to window period or occult hepatitis B infections (OBIs). This study was aimed at evaluating the prevalence of the anti-HBC and identifying the HBV DNA in HBsAg negative blood donors.

Methods: The Blood samples from $2031 \mathrm{HBsAg}$-negative blood donors were divided into three aliquots and tested for anti-HBC, anti-HBs and HBV DNA. Serologic screening including anti-HBC and anti-HBs was performed. As a confirmatory test, all positive results for anti-HBc were retested with another kit. Two positive results were considered for anti-HBC positivity. All HBsAg negative selected donations were tested by PCR assay on pooled specimens (five samples per pool), plasma samples found to be HBsAg negative but anti-HBc positive were selected for a single-unit specimen Real-Time assay.

Results: The study population had a mean age of $33.25 \pm 10.09$ years were mainly composed of males (94.8\%). The seroprevalance rate was $4.9 \%$ for Anti-HBc and $31.9 \%$ for HBsAb. The majority (58.6 \%) of Anti-HBc positive cases were regular blood donors with 42-49 years being the largest age group (41.4\%). Neither individual NAT nor pooled NAT test detected any HBV DNA.

Conclusion: However, Screening of anti-HBC Ab is proposed as a method to identify previous contact with HBV, but there is controversy in literature data regarding the cost-benefit of exclusion of positive anti-HBC $\mathrm{Ab}$ in blood donors. Our data does not suggest HBc-Ab test as a screening tool in the study setting.
\end{abstract}

Keywords: Hepatitis B virus, Blood Transfusion, Blood Donors, Occult hepatitis B virus, Blood safety

\section{Background}

Blood and blood products are inseparable part of the treatment in many medical settings. Therefore, the availability of adequate safe blood and blood products remains a major concern in health care system and transfusion practice. The limited data from WHO Global Database on blood safety indicates around 92 million blood donations worldwide and more than 9 million blood transfusions in ninety countries, annually [1]. Currently, Iran has achieved $100 \%$ voluntary nonremunerated blood donation, and in 2011 about 2

\footnotetext{
* Correspondence: maryam.zad@gmail.com

Blood Transfusion Research Center, High Institute for Research and Education in Transfusion Medicine, Hemmat Exp. Way, Next to the Milad Tower, Tehran,
} Iran

million blood donations were recorded [2]. For a variety practice. However, despite considerable improvements in eligibility criteria for blood donation and development of more advanced screening methods, transfusion transmitted infectious agents like hepatitis B virus still present as a threat for blood safety. Currently About $0.2 \%$ of donated blood from apparently healthy donors in Iran is diagnosed as HBsAg-positive and is hence discarded [2]. This phenomenon is observed on different scales in other blood services across the world [3]. By perceiving the HBV host interaction, it was shown that even HBsAg negative individuals might be infected and there is a 
chance of transmission especially upon transfusion. Thus, despite all efforts including the use of a highly sensitive HBsAg test, transmission may still occur from apparently healthy blood donors. This may be attributed to the inability of the screening tests to detect $\mathrm{HBsAg}$ during a window period or as a result of the occult HBV infections (OBIs). OBI arises when the HBV DNA is detected, while $\mathrm{HBsAg}$ remaining undetectable. In about $20 \%$ of cases the only positive marker is HBV DNA but in other situations anti-HBc or anti-HBs could be detected as well. Several factors may be involved in OBI, including mutated HBsAg, low level expression of HBsAg or entrapment of antigen in the circulatory immune complexes [4-6]. The prevalence of hepatitis B virus infection in the population and the sensitivity of laboratory methods could affect the reported prevalence rates of OBI [7]. Some studies have suggested that in HBsAg negative and anti-HBc positive cases, there is a possibility of low level infectious HBV viremia. This study was conducted in order to determine the frequency of anti-HBc and HBV DNA in blood donors with undetectable HBsAg. Since HBsAg test is the only screening method in Iranian blood donation centres, the necessity for supplemantary screening tests such as anti$\mathrm{HBc}$ or NAT test were studied as well.

\section{Methods}

During the time frame of the present study (2013), 86,182 blood donations from voluntary blood donors in two main blood collection centres (Kermanshah and Ahwaz) were evaluated for HBsAg. HBsAg positive donors were excluded and HBsAg negative donors were considered for inclusion in the study. The donors were categorized as first-time, repeated and regular donors on the basis of blood donation history and according to the definition by Iranian Blood Transfusion Organization (IBTO). Based on the calculated sample size, a total of $2031 \mathrm{HBsAg}$ negative donations were randomly selected. The samples were centrifuged and plasma was separated. Each sample was divided into three aliquots and stored at $-70{ }^{\circ} \mathrm{C}$ for further processing. The samples screened for anti-HBc, anti-HBs and HBV DNA according to standard procedures carried out in the laboratories of IBTO. This study was approved by the IBTO Ethics Committee. Anti-HBc positive and negative subjects were further studied in terms of demographic variables such as age, gender, occupational status, in addition to blood donation and vaccination history.

\section{ELISA tests}

Serologic screening including anti-HBc (Cut-off $=(\mathrm{NC}+\mathrm{PC}) / 5 ; \mathrm{OD}=450 \mathrm{~nm} ;$ positivity of $>1.1)$ and anti-HBs were tested (DIA.PRO Diagnostic Bioprobes s.r.l, Milano, Italy) according to the manufacturer's instructions. All positive results for anti-HBc were retested with another kit (IgM-IgG-HBc Ab DADE Behring, Germany). Two positive results were considered for anti-HBc positivity.

\section{Detection of HBV DNA}

All HBsAg negative selected donations were tested by PCR assay on pooled specimens (five samples per pool) plasma samples found to be HBsAg negative but anti$\mathrm{HBC}$ positive were selected for a single-unit specimen Real-Time assay. HBV-DNA was extracted from $200 \mu \mathrm{l}$ of plasma by using the QIAamp DSP virus purification kit (Qiagen $\mathrm{GmbH}$, Hilden, Germany) and detected with a commercial PCR kit (Qiagen GmbH, 4 Hilden, Germany) on a Light Cycler instrument (Roche Diagnostics-version2) according to the protocols recommended by the manufacturers. In each run, we used plasma negative and positive samples to prevent false positive and negative results. Also, to verify both steps DNA extraction and inhibition in PCR reaction, internal control was used for all samples. The lower detection limit for Real-Time PCR in this study was $9 \mathrm{IU} / \mathrm{mL}$. Also, for confirmation of the results obtained, another sensitive in house HBV-DNA NAT was used that the sensitivity of the assay for HBV-DNA was $30 \mathrm{IU} / \mathrm{ml}$. The analytical sensitivity of the PCR test was assessed using triplicate analysis of 10-fold serial dilutions of the world health organization (WHO) international standard for HBV (NIBSC; Hertfordshire, United Kingdom). The $95 \%$ detection limits of the assays were calculated by probit analysis. The lower limit of detection of the PCR was $20 \mathrm{IU} / \mathrm{ml}$. Clinical specificity was determined using 100 blood donor samples that were negative for HBV DNA, resulting in a clinical specificity of $100 \%$. The clinical sensitivity of the PCR assay was determined using a low-titer dilution series of an HBV genotype D specimen. HBV DNA was diluted to concentrations of $150,125,100,75,40,30,20$ and $10 \mathrm{IU} / \mathrm{ml}$. The lower limit of detection of the PCR was $30 \mathrm{IU} / \mathrm{ml}$. For detecting all of the HBV genotypes, WHO International Reference Panel, containing hepatitis B virus genotypes A-G was used for assays.

\section{Results}

During the study period, 86,182 units of blood from volunteer donors were collected. A total of $102(0.12 \%)$ blood donors were HBsAg positive and therefore were not further evaluated. As shown in flow-chart, the results of this study were obtained from three laboratory tests: Anti-HBc, Anti-HBs and NAT (Fig. 1). Anti-HBc positivity rate was $4.9 \%(99 / 2031)$. The study population consisted of 1928 males (94.92\%) and 103 females (5.08\%), between 18 and 65 years with a mean age of $33.25 \pm 10.09$. The anti-HBs positivity rate was $31.9 \%$ 


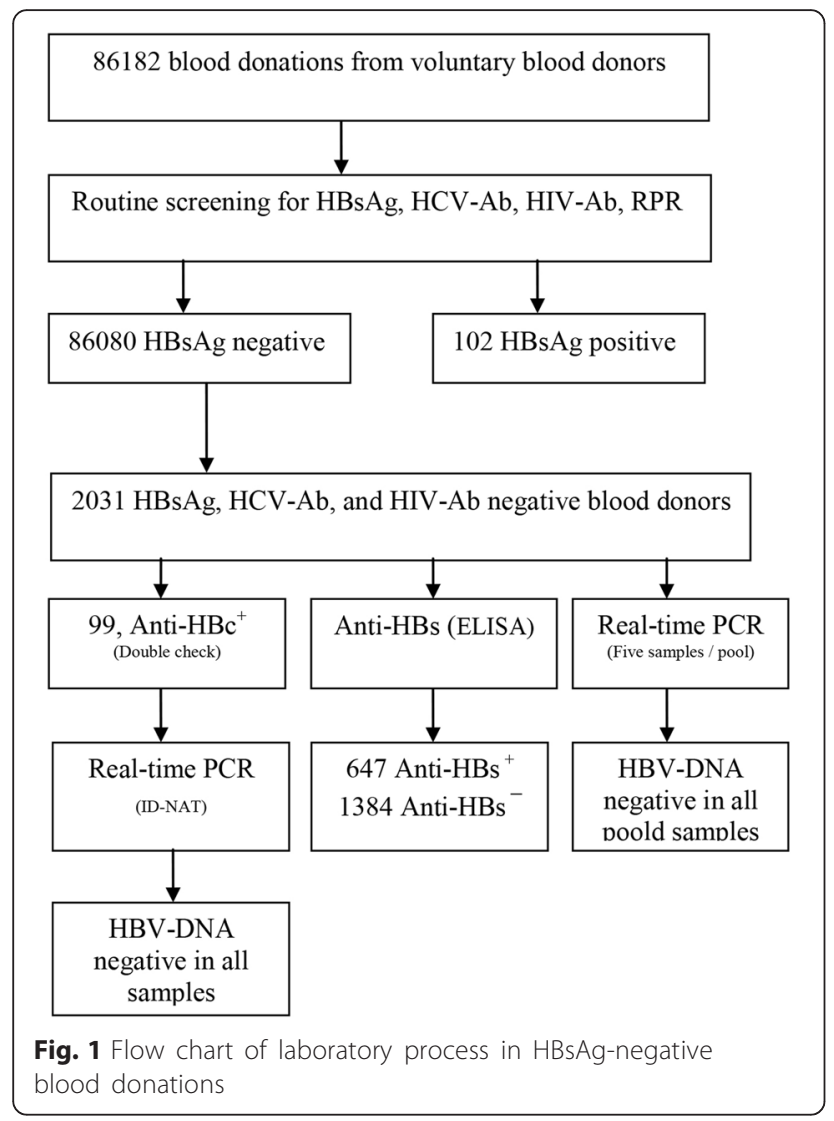

$(647 / 2031)$ among the entire study population. It is reported a vaccination history in 591 (29\%) of blood donors of which 380 (64.3\%) were Anti-HBs positive. The majority (98.9\%) of Anti-HBc positive donors were male and mainly from the $42-49$ year age group (41.4\%). There were statistically significant differences between Anti-HBc positive and negative donors in age groups $(p=0.001)$. In anti-HBc positive subjects, $15.2 \%(15 /$ 99) were anti-HBs negative. Fifty-eight (58.6\%) of anti-HBc positive individuals were regular blood donor. statistically significant relationship was observed between anti-HBc positivity and regular blood donation $(P=0.001)$. All of the 99 anti-HBc positive samples that were tested by individual nucleic acid test were HBV DNA negative. Moreover, pooled NAT (five samples per pool) on the HBsAg negative samples (2031) did not show HBV DNA in any sample (Table 1 ).

\section{Discussion}

Detection of hepatitis B virus in blood donors with Australia antigen test (HBsAg test) began in 1970. In respect to the above mentioned issue, Iranian Blood Transfusion Organization since its establishment in 1974 has screened all donated blood for hepatitis B virus.

In 1979, the prevalence of HBsAg among voluntary blood donors in Iran was reported to be $3.4 \%$ [8]. However this rate has been dramatically decreased over the past 30-35 years and the current prevalence rate of HBsAg among voluntary blood donors has reached to $0.2 \%$ [2], with variations between different regions. Furthermore, HBV prevalence rate of $2.14 \%$ has been reported in the general population [9]. This decrease could be attributed to the improvement in donor selection procedures along with the application of community based preventive measures such as integration of HBV vaccination in Expanded Programme on Immunization (EPI) since 1993, increased community health education, and development of highly sensitive screening tests. Owing to these safety strategies post transfusion hepatitis is now a very rare event. No evidence about the incidence of post transfusion hepatitis B in Iran has been found. In a review article published by $\mathrm{H}$. Rezvan et al. the prevalence of HBSAg in $\beta$ thalassemia major and haemodialysis patients (as multitransfused patients) has been reported around the general population [10]. Even though, there were no evidence that they are actually infected via blood transfusions. So that, we are not capable to find any evidence in case of post transfusion hepatits B prevalence in Iran. Nevertheless, circulating HBV DNA in HBsAg negative blood donors (occult HBV infection) can be a threat to blood safety. Therefore, performing HBsAg test does not eliminate the risk of HBV transmission to blood recipients completely. It has been reported that OBI is associated

Table 1 Serological prevalence and other characteristics among blood donors

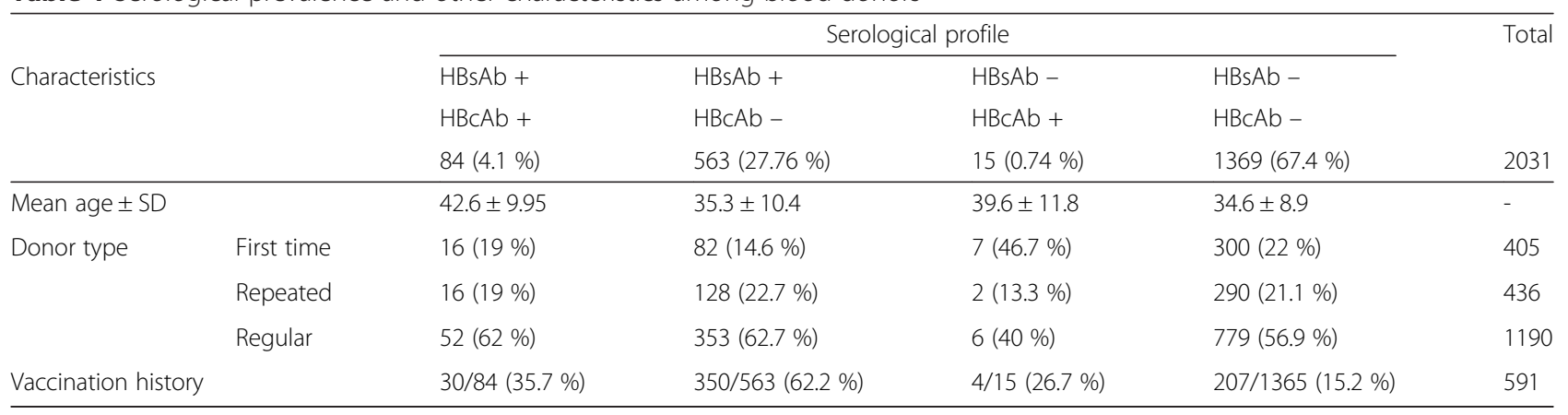


with the presence of anti-HBc or anti-HBs. Even more, in some cases neither anti-HBc can be detected nor anti-HBs [11]. Given the above considerations, it is proposed that implementing genomic screening (NAT) in high and low prevalence countries could lead to substantial safety in view of window period and OBI related risk of transfusion transmitted Hepatitis B. The detection limit of NAT ranges from 1:1000 to 1:50,000 depending on the epidemiology and sensitivity of the assay as described by Alain [3].

The rate of positive serologic test results for anti-HBc was found to be $4.9 \%$ in the present study and isolated anti-HBc were found in 15 cases $(0.74 \%)$. In the literature, anti-HBc prevalence rates between 2.1 and $11.5 \%$ has been reported among Iranian blood donors (Table 2), and the prevalence of anti-HBc in Iranian general population has been reported to be $16.4 \%$ [22]. Thus, our results are in accordance with the literature data. The slight differences between our results and the previous ones may be described by many factors such as different sample size, laboratory methods, and different epidemiological conditions.

Several conditions may result in positive isolated anti$\mathrm{HBc}$ in an apparently healthy blood donor. One possibility is recovered past HBV infection, which did not apply to our donors as they had no history of hepatitis. Nevertheless, hepatitis B infections are sometimes asymptomatic and patients do not manifest jaundice or any other symptoms/signs. Another possibility is false-positive results due to be poor specificity of the test [23]. To minimize false-positive results, we repeated the test with the same method, and all reactive samples were positive in repeated measurements. Finally, there is risk of HBV transmission in pre-seroconversion widow period, i.e. a period that infected blood donors have not been seroconvert yet, hence $\mathrm{HBsAg}$ and anti- $\mathrm{HBc}$ are negative. Therefore, in addition to anti-HBc positive cases, all HBsAg negative samples were also evaluated by minipool nucleic acid testing. Our study demonstrated an anti-HBs prevalence rate of $31.9 \%(647 / 2031)$ in $\mathrm{HBsAg}$ negative blood donors. Specimens from 84 blood donors were positive for both anti-HBs and anti-HBc. Thus, 563 blood donors were positive for anti-HBs alone. Regarding the vaccination history of 591 cases, it appears that in spite of vaccination, 28 subjects could not produce the HBsAb response.

Considering the fact that concurrent detection of anti$\mathrm{HBc}$ and anti-HBs might be assessed as an indicator of past exposure and recovery, it can be inferred from our results that $4.1 \%$ of our donors had a history of infection, and were immune due to previous exposure/infection. There is evidence that HBV DNA can be detected even in anti-HBs positive blood donors [24, 25]. Thus it has been suggested that the presence of anti-HBs antibody does not rule out the possibility of HBV transmission. In this study, no HBV DNA in the serum samples of HBsAg negative blood donors was detected regardless of positive or negative anti-HBc and anti-HBs test results. A review of the similar published studies in Iranian blood donors shows different statistics. According to a review of 11 published articles, the prevalence of $\mathrm{HBV}$ DNA in HBsAg negative/anti-HBc positive blood donors varied from 0 to $50 \%$ (Table 2). These studies have been carried out in different geographical areas and also have used different PCR methods such as qualitative, real time and nested PCR. Our study as well as three other studies suggests the absence of OBI in the studied blood donors. Therefore it may be suggested that these results may be influenced by methods and/or laboratory conditions (sampling condition, testing methods and

Table 2 Reported prevalence of Anti-HBc, HBV DNA and OBI in HBsAg Negative blood donors based on some published studies in Iran

\begin{tabular}{|c|c|c|c|c|c|}
\hline Reference & City & Number of donors ( $\left.\mathrm{HBsAg}^{-}\right)$ & Anti-HBC ${ }^{+}$n (\%) & $\mathrm{HBV} \mathrm{DNA}^{+} / \mathrm{Anti}^{-\mathrm{HBC}^{+} \mathrm{n}(\%)}$ & $\overline{O B I} n(\%)$ \\
\hline Sofian et al. [12] & Arak & 531 & $11(2.1 \%)$ & $0 / 11(0 \%)$ & 0 \\
\hline Shahabi et al. ${ }^{a}$ & Mashhad & 5059 & $432(8.5 \%)$ & $0 / 60(0 \%)$ & 0 \\
\hline AminiKafi-abad et al. [13] & Tehran & 2000 & $230(11.5)$ & 0/230 (0 \%) & 0 \\
\hline Khamesipour et al. [14] & Rasht & 2041 & $78(3.8 \%)$ & $1 / 78(1.3 \%)$ & $1(0.05 \%)$ \\
\hline Pourazar et al. [15] & Isfahan & 545 & $43(8 \%)$ & $5 / 43(11.62 \%)$ & $5(0.92 \%)$ \\
\hline Behbahani et al. [16] & Shiraz & 2000 & 131 (6.55\%) & 16/131 (12.2\%) & $16(0.8 \%)$ \\
\hline Arababadi et al. [17] ${ }^{\text {a }}$ & Rafsanjan & 3700 & $352(9.51 \%)$ & $57 / 352(16.1 \%)$ & $57(1.54 \%)$ \\
\hline Jafarzadeh et al. [18] & Rafsanjan & 270 & $14(5.18 \%)$ & 4/14 (28.57\%) & $4(1.48 \%)$ \\
\hline Delavari et al. [19] & Kerman & 1525 & $121(8 \%)$ & 36/121 (29.7 \%) & $36(2.36 \%)$ \\
\hline Vaezjalali et al. [20] & Tehran & 1000 & $80(8 \%)$ & $40 / 80(50 \%)$ & $40(4 \%)$ \\
\hline Alizadeh et al. [21] & Tehran & 5000 & 499 (9.8\%) & 2/499 (0.4\%) & $2(0.04 \%)$ \\
\hline Total & - & 23,671 & 1991 (8.4 \%) & $161(9.9 \%)$ & $161(0.7 \%)$ \\
\hline
\end{tabular}

${ }^{a}$ Article published in Persian 
equipment) used by different researchers. Vaezjalali et al, who reported the highest frequency, claimed improved accuracy of HBV DNA detection through the use of a homemade nested PCR technique with at least two different sets of primers in their study. In a study conducted earlier by Shahabi et al (article in Persian) this method has been used as well. In the mentioned article, there was no evidence of HBV DNA in 60 samples.

The results of similar studies on the frequency of HBV-DNA positivity in HBsAg negative, anti-HBc positive blood donors in other countries show great variation. The frequency was reported $0 \%$ in Turkey and Greece [26-28], $1.25 \%$ in Saudi Arabia [29], $1.59 \%$ in Germany [23], $4.86 \%$ in Italy [30], $7.5 \%$ in India [31], $17.2 \%$ in Egypt [32], 38 \% in Japan [33] and $90.5 \%$ in Sudan [34].

Differences in the frequencies of occult HBV infection in different studies could be related to the endemicity of HBV infection, geographical variations, the sensitivity of the screening tests being used to detect HBV DNA and other viral markers, sample size, power of the study, composition of study population and so on.

Evidence shows that anti-HBc testing has only a little effect on the blood safety. However, the use of individual NAT test can improve the HBV related blood safety. In spite of introducing the individual NAT test, transfusion centres cannot bypass the serological tests and various combinations of serology and NAT are implemented in different countries [3]. Currently, about 27 countries in the world have implemented NAT for hepatitis B virus screening in blood donors as a mandatory or voluntary approach [35]. High coverage of HBV vaccination in the early infantile period (around $97 \%$ ) was achieved and consequently a marked decrease in the HBV prevalence among general population was reported. In addition, vaccination in the health care workers has been implemented since 1993 and mass vaccination for adolescents who was born from 1989 to 1992 was also performed to extend the immunity to larger group of young population. Moreover, a series of studies on the general population have shown that the efficacy of hepatitis B vaccine has been more than $80 \%[36,37]$. The combined effect of vaccine and improvement on public health status resulted change in the HBV epidemic and Iran now is in a low-intermediate state. So that the epidemiological feature of virus in Iran might be presented as a describing factor to decrease the necessity of NAT test on Iranian blood donors.

\section{Conclusions}

Occult HBV infection is a complex issue especially given the fact that many circumstances and conditions may influence the clinical and laboratory findings. In order to detect HBV-DNA in very low levels, it is necessary to use a highly sensitive technique.

In this study, HBV-DNA in anti-HBc seropositive blood donors could not be detected. Therefore, based on our data it is not suggested to screen anti-HBc or HBV NAT in Iranian blood donors. On the other hand, different rates of occult HBV infection in blood donors are reported across the country. In addition it should be considered that anti-HBc screening of the blood donors will lead to the loss of a significant number of donors. For example, in our experience, screening the donors for anti-HBc could result in approximately $5 \%$ loss in blood donations, without significant evidence that such condition could affect the blood safety. Therefore, the decision on implementing the anti-HBc and HBV NAT should be based on more comprehensive, multicenter studies to perceive the actual amount of occult HBV infection in the general population and blood donors.

\section{Competing interests \\ The authors declare that they have no competing interests.}

\section{Authors' contributions}

GK designed the research, gathered the data and revised the article. NF gathered and analyzed the data. ZS revised the manuscript. MF interpreted the data. $M Z$ reviewed the literature, wrote the manuscript and revised the article. All authors read and approved the final manuscript.

\section{Acknowledgments}

The authors would like to thank the staff of Blood transfusion research centre who contributed to this work.

Compliance with ethical guidelines.

Received: 3 January 2016 Accepted: 22 February 2016

Published online: 05 March 2016

\section{References}

1. Global Database on Blood Safety, Summary Report 2011, available at: http://www.who.int/bloodsafety/global_database/GDBS_Summary_ Report_2011.pdf?ua=1. Accessed 28 July 2015 .

2. Cheraghali A. Overview of blood transfusion system of iran: 2002-2011. Iran J Public Health. 2012:41:89-93.

3. Allain JP, Cox L. Challenges in hepatitis B detection among blood donors. Curr Opin Hematol. 2011;18:461-6.

4. Cabrerizo M, Bartolome J, Caramelo C, Barril G, Carreno V. Molecular analysis of hepatitis $B$ virus DNA in serum and peripheral blood mononuclear cells from hepatitis B surface antigen-negative cases. Hepatology. 2000;32:116-23.

5. Zaaijer HL, Torres P, Ontanon A, Ponte LG, Koppelman MH, Lelie PN, et al. Multiple surface antigen mutations in five blood donors with occult hepatitis B virus infection. J Med Virol. 2008:80:1344-9.

6. Said ZN. An overview of occult hepatitis B virus infection. World J Gastroenterol. 2011;17:1927-38.

7. Raimondo G, Pollicino T, Cacciola I, Squadrito G. Occult hepatitis B virus infection. J Hepatol. 2007;46:160-70.

8. Farzadegan $\mathrm{H}$, Harbour C, Ala F. The prevalence of hepatitis B surface antigen and its antibody in blood donors and high risk groups in Iran. Vox Sang. 1979;37:182-6.

9. Alavian SM, Hajarizadeh B, Ahmadzad-Asl M, Kabir A, Bagheri-Lankarani K. Hepatitis B Virus infection in Iran: A systematic review. Hepat Mon. 2008;4: 281-94.

10. Rezvan $H$, Abolghassemi H, Kafiabad SA. Transfusion transmitted infections among multitransfused patients in Iran: a review. Transfus Med. 2007;17: 425-33.

11. Hollinger FB. Hepatitis B, virus infection and transfusion medicine: science and the occult. Transfusion. 2008;48:1001-26. 
12. Sofian M, Aghakhani A, Izadi N, Banifazl M, Kalantar E, Eslamifar A, et al. Lack of occult hepatitis $B$ virus infection among blood donors with isolated hepatitis B core antibody living in an HBV low prevalence region of Iran. Int J Infect Dis. 2010;14:e308-10.

13. Amini K, Talebian A, Moghtadaie M, Ranjbar K, Ferdowsian F, Samie S, et al. Detection of hepatitis $B$ virus DNA [PCR] in HBsAg negative, anti-HBC positive blood donors in Tehran province. Blood J. 2004;3:379-87.

14. Khamesipour A, Amiri ZM, Kafiabad SA, Saadat F, Mansour-ghanaei F, Esteghamati AR, et al. Frequency of hepatitis $B$ virus DNA in anti-HBC positive, HBsAg negative blood donors in Rasht, northern Iran. Transfus Apher Sci. 2011;45:195-7.

15. Pourazar A, Salehi M, Jafarzadeh A, Arababadi MK, Oreizi F, Shariatinezhad K. Detection of HBV DNA in HBsAg negative normal blood donors. IJI. 2005;2: 172-6.

16. Behzad-Behbahani A, Mafi-Nejad A, Tabei S, Lankarani K, Torab A, Moaddeb A. Anti-HBC \& HBV-DNA detection in blood donors negative for hepatitis $B$ virus surface antigen in reducing risk of transfusion associated HBV infection. Indian J Med Res. 2006;123:37-42.

17. Arababadi MK, Pourfathollah AA, Jafarzadeh A, Hassanshahi G, Afrooz MR, Hadadian M. Occult HBV infection in Rafsanjanese blood donors. Modares J Med Sci. 2009;11:81-6.

18. Jafarzadeh A, Arababadi MK, Pourazar MMA. Occult hepatitis B virus infection among blood donors with antibodies to hepatitis B core antigen. Acta Med Iran. 2008;46:27-32.

19. Delavari M. Frequency of Anti-HBc \& HBV DNA detection in blood donors of Kerman province, Iran. J Blood Disord Transfus. 2011;2:1-4.

20. Vaezjalali M, Rashidpour S, Rezaee H, Hajibeigi B, Zeidi M, Gachkar L, et al. Hepatitis B viral DNA among HBs antigen negative healthy blood donors. Hepat Mon. 2013;13:e6590.

21. Alizadeh Z, Milani S, Sharifi Z. Occult hepatitis B virus infection among Iranian blood donors: a preliminary study. Arch Iran Med. 2014;17:106-7.

22. Merat S, Rezvan H, Nouraie M, Jamali A, Assari S, Abolghasemi H, et al. The prevalence of hepatitis B surface antigen and anti-hepatitis B core antibody in Iran: a population-based study. Arch Iran Med. 2009;12:225-31.

23. Schmidt M, Nubling CM, Scheiblauer H, Chudy M, Walch LA, Seifried E, et al. Anti-HBC screening of blood donors: a comparison of nine anti-HBC tests. Vox Sang. 2006;91:237-43.

24. Hennig H, Puchta I, Luhm J, Schlenke P, Goerg S, Kirchner H. Frequency and load of hepatitis B virus DNA in first-time blood donors with antibodies to hepatitis B core antigen. Blood. 2002;100:2637-41.

25. Ashshi AM. Detection of occult hepatitis B virus in anti-HBC positive/antiHBs positive blood donors in Saudi Arabia. Res J Med Sci. 2012;6:61-5

26. Findik D, Arslan U, Baykan M. Determination of hepatitis $B$ virus DNA incidence, viral load, and mutations in blood donors with HBsAg and antiHBs-negative serology and antibodies to hepatitis B core antigen. Eur J Intern Med. 2007;18:571-5.

27. Arabaci F, Oldacay M. Investigation of mutant Hepatitis B virus in core antibody seropositive cases of blood donor population. J Med Sci. 2008;8: 316-20.

28. Zervou EK, Dalekos GN, Boumba DS, Tsianos EV. Value of anti-HBc screening of blood donors for prevention of HBV infection: results of a 3-year prospective study in Northwestern Greece. Transfusion. 2001;41:652-8.

29. Zekri AR, Awlia AA, El Mahalawi H, Ismail EF, Mabrouk GM. Evaluation of blood units with isolated anti HBC for the presence of HBV DNA. Dis Markers. 2002;18:107-10

30. Manzini P, Girotto M, Borsotti R, Giachino O, Guaschino R, Lanteri M, et al. Italian blood donors with anti-HBC and occult hepatitis B virus infection. Haematologica. 2007;92:1664-70.

31. Asim M, Ali R, Khan LA, Husain SA, Singla R, Kar P. Significance of anti-HBC screening of blood donors and its association with occult hepatitis B virus infection: Implications for blood transfusion. Indian J Med Res. 2010;132: 312-7.

32. Said ZN, Sayed MH, Salama II, Aboel-Magd EK, Mahmoud MH, Setouhy ME, et al. Occult hepatitis B virus infection among Egyptian blood donors. World J Hepatol. 2013;5:64-73.

33. Yotsuyanagi $H$, Yasuda $K$, Moriya K, Shintani $Y$, Fujie $H$, Tsutsumi $T$, et al. Frequent presence of HBV in the sera of HBsAg-negative, anti-HBc-positive blood donors. Transfusion. 2001;41:1093-9.

34. Mahmoud OA, Ghazal AA, Del Metwally S, Elnour AM, Yousif GE. Detection of occult hepatitis B virus infection among blood donors in Sudan. J Egypt Public Health Assoc. 2013;88:14-8.
35. Roth WK, Busch MP, Schuller A, Ismay S, Cheng A, Seed CR, et al. International survey on NAT testing of blood donations: expanding implementation and yield from 1999 to 2009. Vox Sang. 2012;102:82-90.

36. Alavian S, Lankarani K. Hepatitis B virus infection; a vanishing disease in Iranian children. J Compr Ped. 2012;3:1-2.

37. Tazhibi $M$, Hajivandi A, Tafti AD, Fallahzadeh $H$. The efficacy of hepatitis $B$ vaccine in Iranian population: a systematic review and meta-analysis. J Edu Health Promot. 2014;3:53.

\section{Submit your next manuscript to BioMed Central and we will help you at every step:}

- We accept pre-submission inquiries

- Our selector tool helps you to find the most relevant journal

- We provide round the clock customer support

- Convenient online submission

- Thorough peer review

- Inclusion in PubMed and all major indexing services

- Maximum visibility for your research

Submit your manuscript at www.biomedcentral.com/submit
Biomed Central 